\title{
Jesuit Catechisms for Soldiers (Seventeenth- Nineteenth Centuries): Changes and Continuities
}

\author{
Vincenzo Lavenia \\ Università di Macerata, Italy \\ v.lavenia@unimc.it
}

\begin{abstract}
This paper proposes a literary journey through the manuals for soldiers written by Jesuits prior to the twentieth century. After briefly outlining the debut of these publications, at the hands of Antonio Possevino and of Thomas Sailly, who led the first permanent mission of military chaplains in Flanders, it will focus on three moments: the second half of the seventeenth century, when the wars of religion wound down and we find the first manuals where, alongside the desire to impose discipline on armies, a patriotic rhetoric begins to be heard; the middle years of the eighteenth century, before the French Revolution, when, after the establishment of barracks and permanent chaplaincies, even texts aimed at the Christian soldier transposed the vocabulary of the Droit des gens in; finally, the nineteenth century, when the Society was restored and undertook the religious conversion of the soldiery against the perils of the modern world. In Belgium, the birth of a liberal Catholic regime supported a patriotically-toned missionary effort from Jesuit chaplains. Later, the mystique of the nation would affect the majority of texts aimed at combatants and their chaplains during the Great War.
\end{abstract}

\section{Keywords}

soldiers' catechisms - Jesuit military chaplains - Thomas Sailly - Alonso de Andrade Thomas Le Blanc - Pierre Daguet - Antonio Cordoniu - Giovanni Regoli - Paul Barbieux - Jean Baptiste Boone

As recent studies have highlighted, two Jesuits, Emond Auger (1530-91) and Antonio Possevino (1533-1611), were the originators, in the wake of the Council 
of Trent, of the genre of catechisms aimed at soldiers, which is the subject of this article. ${ }^{1}$ During the years in which the wars of religion were bloodying France and Flanders, in an age of continual clashes with Ottoman forces, the existing Christian literature directed at those exercising the profession of arms (which consisted of a clutch of St. Augustine's letters, St. Bernard's Laus ad milites templi, and other writings that would go on being reprinted even after the sixteenth century $)^{2}$ was replaced by manuals exhorting sacrifice in the name of the faith, but also envisaging a universal discipline for the officers and men enrolled in ever larger armies, to rehabilitate the art of war in the face of the accusation that it was practiced by vicious and brutal marauders. It was above all Possevino's Il soldato christiano (1569, and many times reprinted) that provided the model, which would then be adapted to different contexts (as in Poland by Piotr Skarga, $1536-1612$ ). ${ }^{3}$ His was a lively vernacular text, alternating quotes on the wars of the Old Testament with stories of heroes who had fought in the Crusades and making assaults on Erasmian irenicism with justifications for holy and just wars aimed at annihilating the enemies of the Roman faith. Soldiers were exhorted to pray, confess, and take Communion; to trust in the God of Battles, who was on the side of Catholicism; and to curb violence against civilians. Possevino also lists the vices they should eliminate in themselves (lust, blasphemy, drunkenness, robbery, gambling, and dueling)

1 Emond [Auger], Le pédagogue d'armes (Paris: Nivelle, 1568). On Auger, see Gianclaudio Civale, "Religione e mestiere delle armi nella Francia dei primi torbidi religiosi: Il 'Pedagogue d'Armes' del gesuita Emond Auger (1568)," Bibliothèque d'Humanisme et Renaissance 74 (2012): 505-33; Ariane Boltanski, “Forger le 'soldat chrétien': L'encadrement catholique des troupes pontificales et royales en France en 1568-1569," Revue historique 669 (2014): 51-85; Vincenzo Lavenia, Il catechismo dei soldati: Guerra e cura d'anime in età moderna (Bologna: Edb, 2014).

Textual quotations have been translated and information on the authors of catechisms kept to a minimum. Further material can be found in repertories and standard works on the Jesuits; see especially Carlos Sommervogel, Bibliothèque de la Compagnie de Jésus, 12 vols. (Brussels-Paris-Toulouse: Schepens-Picard-Chez l’Auteur, 1890-1932); László Polgár, Bibliographie sur l'histoire de la Compagnie de Jésus, 1901-1980, 6 vols. (Rome: I HSI, 1981-90); Charles O’Neill and Joaquín M. Domínguez, eds., Diccionario histórico de la Compañía de Jesús: Biográfico-temático, 4 vols. (Rome-Madrid: IHSI-Universidad Pontificia Comillas, 2001). For Possevino see below. For a bibliography on chaplains and religious literature for soldiers, see my introduction to this thematic issue.

2 A Jesuit republished Ferrandus Diaconus's old Paraeneticus ad Reginum Comitem, qualis esse debeat dux religiosus in Flanders, under a new title: Juan Bautista Villalpando, Oficio del capitán y soldado católico (Amberes: Bellero, 1612).

3 See Mirosław J. Lenart, "La 'nuova' religiosità dei soldati polacchi dopo il Concilio di Trento," in Lingue e testi delle riforme cattoliche in Europa e nelle Americhe (sec. XVI-XXI), ed. Rita Librandi (Florence: Cesati, 2012), 77-92. 
by means of a physical and moral disciplinary regime which he later specified in the Book v of his Bibliotheca selecta (1593). In that work, written before the establishment of barracks, the Jesuit imagined the founding of "soldiers' seminaries" for the education of Christian troops, outlining a selection of books to be read for the nourishment of the soul as well as for instruction in the arts of war. ${ }^{4}$

Possevino's model was an abstract one and his manual did not deter some Jesuits from continuing to write more or less appropriate texts for both officers and common soldiers. ${ }^{5}$ The armies of the day, besides, remained brutal and undisciplined for all that the figure of the army chaplain, from a variety of religious orders, began to appear more often alongside the soldiery. Pastoral work became nonetheless a more stable phenomenon when a group of Jesuits from the Flandro-Belgica province inaugurated the first organized mission of military chaplains (the missio castrensis et navalis). At their head was Thomas Sailly (1553-1623), who was close to Alessandro Farnese (1545-92), to Justus Lipsius (1547-1606), to the Plantin printing house and to Possevino, and who reworked Il soldato christiano into an illustrated catechism for French-speaking chaplains and soldiers. The Guidon et pratique spirituelle du soldat (1590) encouraged pastors not to limit themselves to purely spiritual sustenance but also to comfort the wounded in hospitals and soldiers on the point of death, helping them with their testamentary wishes. As Sailly himself had done, priests and captains should oversee enlistment together, checking the religious denominations of recruits and identifying the most suitable men to form a confraternity capable of physically and spiritually assisting the weakest. Soldiers were often given to reading irreligious works, for example of Machiavellian hue; and their sins were gross: some even stole from their dead companions, many practiced superstitions, others were perjurers. Sieges often resulted in violence against civilians. Sailly condemned these vices and, in addition to classical and biblical exempla, provided more recent stories demonstrating the superiority of Catholics worldwide. Further, he insisted on prayer, preparing a calendar setting out the dates of great victories over heretics and infidels and the feast days

4 Antonio Possevino, Il soldato christiano con l'instruttione dei capi dello essercito catolico (Rome: Dorici, 1569). On the author, see John Patrick Donnelly, "Antonio Possevino's Plan for World Evangelization," The Catholic Historical Review 74 (1988): 179-98; Robert A. Maryks, The Jesuit Order as a Synagogue of Jews: Jesuits of Jewish Ancestry and Purity-of-Blood Laws in the Early Society of Jesus (Leiden: Brill, 2009); Emanuele Colombo, "Possevino, Antonio," in Dizionario biografico degli italiani, vol. 85 (Rome: Istituto della Enciclopedia Italiana, 2016) (the entry contains a very helpful bibliography).

5 See the very learned Latin text of the Polish Matthaeus Bembus, Bellator christianus, hoc est ratio Christiane, pie, feliciterque bella et apparandi et gerendi (Cologne: Birckmann, 1617). 
of warrior saints: Loyola, not yet canonized, also figured in this list. Finally, shortly before his death, Sailly recorded his own experiences in a Memorial testamentaire, which appeared posthumously. ${ }^{6}$

Prior to publishing his Guidon, Sailly had also translated and adapted Possevino's catechism into Spanish: well aware that armies were a Babel of languages, he addressed himself to the soldiers and chaplains of the tercios who understood neither Italian or French. ${ }^{7}$ As it happened, a Portuguese brother, Francisco António, had also the idea at much the same time of preparing a text for the Spanish soldiery, his Avisos para soldados (1590), dedicated to Albert of Austria (1559-1621). ${ }^{8}$ The author boasted of the originality of his work: although there was no shortage of literature for officers, that aimed at the common soldier was meager. He started from the legitimacy of war, which the simple soldier ought never to question. The massacre of heretics and infidels was a procedure reassuring to the soul and conducive to victory, but war should be conducted with a minimum of looting — justified by pay being in arrears - and avoiding sacrilege and abuses against the clergy, nuns, foreigners, merchants, old people, women, and children. As things were, soldiers were given to behaving like a swarm of locusts. Officers should not defraud the men under them by keeping back a part of their pay and chaplains should try to substitute innocuous pastimes (ballgames, hunting, and chess) for those leading to sinfulness. Soldiers were not easy to catechize, but one could get them into the habit of observing religious festivals and visiting the wounded. As for rulers, they should listen to theologians and sequester nothing without compensation. Moderate taxation and skillful preachers and confessors should be sufficient to maintain a war effort. Chaplains would not dress like soldiers or take part in battles, because in the common struggle against the enemy, the clergy and the military should maintain distinct identities. ${ }^{9}$

6 Thomas Sailly, Guidon et pratique spirituelle du soldat chrétien (Antwerp: Plantin, 1590); Sailly, Memorial testamentaire composé en faveur des soldats (Leuven: Hastens, 1622).

7 See Correspondance de Christophe Plantin, ed. Jean Denucé (Nendeln: Kraus Reprint, 1968, $1^{\text {st }}$ ed. 1918), 8-9:426. Adapting catechisms to different national contingents fighting under the same flag was a necessity. According to Sommervogel, around 1628 the Belgian Jesuit Guillaume Hardigny wrote some Livres de prières [...] pour les soldats allemands; and in 1703, Jean Le Grand published in Douai a catechism in Italian for the soldiers coming from the peninsula.

8 The catechism was published a few years later in Italian; but the author's last name on the frontispiece is curiously different: Francisco Arias, Il soldato christiano, overo christiani ricordi (Venice: Bertoni, 1609).

9 Francisco Antonio, Avisos para soldados y gente de guerra (Madrid: Madrigal, 1590). For the Spanish catechisms, see Enrique García Hernán, "Capellanes militares y Reforma Católica," 
If these were the first examples of Jesuit catechisms for soldiers, the following pages will try to elucidate how the genre underwent modifications up until the twentieth century, homing in on three moments: the second half of the seventeenth century when the wars of religion came to an end and manuals began to appear in which a patriotic rhetoric came to the fore; the middle years of the eighteenth century, before the French Revolution, when, following the establishment of barracks and permanent chaplaincies, texts for Christian soldiers began to absorb the vocabulary of the droit des gens; the nineteenth century, when the Society was resurgent during a period in which the Roman Church fought, in what it saw as a hostile environment, for the religious conquest of armies, only to give way, little by little, to the exaltation of the nation.

I did not find evidence that the Jesuits produced soldiers' catechisms during the Thirty Years' War, but the conflict between Spain and France, which dragged on until 1659, setting two Catholic nations at each other's throats, spawned a second generation of manuals. The first in the field was again from a subject of Spain, the chaplain Alonso de Andrade (1590-1672). El buen soldado católico was dedicated to the Consejo de Estado y Guerra and appeared at a time when Spanish hegemony was beginning to be weakened by uprisings and the prolongation of conflicts. Thus, with the aim of reconciling "Christianity with the soldiery, virtue with the practice of arms," the text lauded the Spanish empire "spread throughout the world" as the true "pillar" of the Catholic faith. ${ }^{10} \mathrm{~A}$ soldier of Spain was not fighting only for the victory of a nation, but for peace and the defense of the Roman religion. He "will not speak ill of other nations" giving way to a usage "habitual among women and people of small worth"; when a Christian (as with the French), the enemy should be honored with "all due nobility."1l Nonetheless, the Spanish soldier was the most religious and limpio; the Reconquista had endowed the crusading Iberian nobility with a patent of superiority that qualified it to prevail over "the moor, the gentile and

in Guerra y sociedad en la Monarquía Hispánica: Política, estrategia y cultura en la Europa moderna (1500-170o), ed. Enrique García Hernán and Davide Maffi (Madrid: Mapfre, 2006), 2:709-42.

10 The catechism was published again in the years of Francisco Franco: Alonso de Andrade, El buen soldado católico y sus obligaciones, ed. Martín de Riquer (Barcelona: Selecciones Bibliófilas, 1959), 1:15-17.

11 Andrade, El buen soldado, 2:195. 
the heretic in virtue."12 The warrior saint worthy of the keenest veneration was St. James (Santiago), whose name lent lustre to a powerful military order. ${ }^{13}$ A fine example of Christian soldier was the fierce hidalgo Hernan Cortés (1485-1547), who was known to kneel at the feet of priests. ${ }^{14}$ Soldiers should be aware that the practice of arms "ennobles those who follow it"; but for this very reason they must keep themselves free of every taint and from sinful reading: examples of the punishments meted out by God on military sinners were legion. ${ }^{15}$ But in Antonio's manual, the traditional pedagogics of fear were accompanied by more specific passages, such as those on the increased burden of taxation to maintain the war effort in the months preceding the fall of the Count-Duke of Olivares (1587-1645). ${ }^{16}$

A few years later, on the other side of the Pyrenees, Thomas Le Blanc (1599-1669) countered the spread of manuals for Spanish soldiers with a catechism whose title-page made no reference to the Catholic cause: the ongoing conflict, in fact, was not essentially religious in nature and the French armies contained a significant number of Huguenots, a matter on which the Spaniards did not hesitate to criticize the king of France. ${ }^{17} \mathrm{~A}$ large portion of the book was dedicated to prayers and litanies of the saints; ${ }^{18}$ but its aim was chiefly to provide a model of the brave and disciplined soldier capable of standing firm against the vices and crimes (especially sacrilegious ones) typical of the military. Thus a practical guide to behavior followed a long list of the sins and virtues of soldiers, who were encouraged to read histories of France and books on geography and mathematics. ${ }^{19}$ The Jesuit went on to extol his compatriots' conquests and instruct the Christian soldier in amour de la Patrie without seeking to make him a monk "confined to the cloisters" (his language inclined to the classical). ${ }^{20}$ As the examples of Joan of Arc and the French kings showed, "the highest nobility is that gained on the point of one's sword [...]. The King

\footnotetext{
12 Ibid., 1:24.

13 Ibid., 2:127ff.

14 Ibid., 1:30.

15 Ibid., 1:41, 169-73.

16 Ibid., 2:196ff.

17 See Philippe Martin, "Thomas Le Blanc: Une volonté de spiritualiser le soldat," in Liturgie und Lebenswelt: Studien zur Gottesdienst- und Frömmigkeitgeschichte zwischen Tridentium und Vatikanum II, ed. Jürgen Bärsch and Bernhard Schneider (Münster: Aschendorff, 2006), 95-105.

18 Thomas Le Blanc, Le soldat généreux, pour l'utilité de tous les soldats (Pont a Mousson: Guillere, 1655), 270-364.

19 Le Blanc, Le soldat, 224.

20 Ibid., Dedication "Aux soldats françois."
} 
in France rewarded with the finest armor those who had run the greatest risks and performed the finest exploits." He was "an image of the Divinity, who the Lord appoints over us as his Lieutenant on earth." ${ }^{21}$ Henri IV (1589-1610), in fact, had been a great soldier who had fought victoriously in hundreds of battles. ${ }^{22}$ Le Blanc was silent on how that sovereign, before his conversion, had taken the field against Catholics. His idea was to mould patriotic chaplains and soldiers and he was writing at a time when a modern French nationalist rhetoric was beginning to take shape. ${ }^{23}$

One who certainly utilized such an emphasis as a motor of power politics was Louis XIV (1643-1715), during his invasion of Catholic Flanders; and it was in that context, at the beginning of the War of the Spanish Succession, that a Dominican friar recast the French Jesuit Henri Godefroy's catechism to inspire the Habsburg forces in their fight against the Sun King. Opening with a copious passage lifted from the Letters of St. Augustine, this work had originally appeared in 1645; but even if written for an enemy army it was useful to the cause of converting "Bellona, and transforming a false and profane goddess [...] into a devout handmaiden of Jesus Christ." The cause might be a difficult one, but the Society of Jesus had already demonstrated it knew how to formulate "spiritual training" in simple terms to reform the hearts of the bellicose nobility and the common soldiers alike. ${ }^{24}$ The Jesuits, besides, were also engaged in those years on the anti-Turkish front: in fact, following the siege of Vienna, Antonio Foresti, author of a Mappamondo istorico, published, under the banner of holy war, an exhortatory work in Italian for combatants fighting in the Balkans, which enjoyed such success that it was also translated into German. ${ }^{25}$ At the same time catechisms began to be couched in the form of stories about exemplary soldiers. ${ }^{26}$

\footnotetext{
21 Ibid., 46, 49, 260-65.

22 Ibid., 257.

23 For the following years, see David A. Bell, The Cult of the Nation in France: Inventing Nationalism, 1680-1800 (Cambridge, MA: Harvard University Press, 2001).

24 Henry Godefroy, Le soldat chretien [...], revu et augmenté par le R.P. Norbert d'Elbecque (Cologne: d'Egmond, 1700), "Avant-propos."

25 Antonio Foresti, Conforti celesti inviati alle milizie christiane della Sacra Lega contra il Turco (Parma: Rosati, 1686 [Venezia: Bosio, 1686]); see Foresti, Annona coelestis, d.i. HimmelProviant christl. Soldaten wider die Türken (Prag: Gerzabek, 1688).

26 See Jacques Desmothes, Le soldat chrétien, sur l'exemple mémorable d'un soldat du régiment Dauphin, mort à Tournay en réputation de sainteté (Bordeaux: Boé, 1696 [2 $2^{\text {nd }}$ edition]); Jean Claude de Ville, La vie de François Philibert, soldat chrétien (Nancy: Guedon, 1714) [republished in the nineteenth century].
} 
The Society, it should be emphasized, was not the only religious order to produce manuals for soldiers, and indeed, from the early seventeenth century, there was a notable production of Protestant texts that proliferated in England in particular during Civil War years. ${ }^{27}$ Later, after Westphalia, violence against civilians diminished, in Europe at least, and the inter-confessional conflicts were relatively "neutralized," without disappearing altogether. Catholic and Protestant chaplains were integrated into the hierarchy of national land and sea forces, and by the end of the seventeenth century, the era of professionalized armies in barracks was dawning. ${ }^{28}$ The climate of holy war that had favored the production of Christian soldier literature faded away paripassu with the Spanish hegemony. The creation of a disciplinary framework regulated by civilian ordinances pushed the clergy into a secondary role, both in the military schools and in the field. But it was in this context that the education of armies and the rules of ius in bello took on an importance that had only been hinted at in the earlier catechisms. Traditional credences were threatened by advancing secularization, and religious manuals became more explanatory and less rhetorical, as can be seen from the texts produced by Jesuits, who in many cases, as well as working as chaplains and in hospitals, became teachers in military academies. The Society, in this context, held up its own organization as a model army and eulogized its founders as ideal soldiers.

In 1751, contemporaneous with the foundation of the French École Royale Militaire, a collection of official decrees was promulgated, which included pastoral provisions drawn up by the archbishop of Paris; furthermore, a few years earlier, a pamphlet for soldiers had been published, perhaps written by a serving

27 See Vincenzo Lavenia, "Foi et discipline: Catéchismes espagnols pour les soldats au temps de la Guerre de Trente Ans," in Religion et piété au défi de la guerre de Trente Ans, ed. Bertrand Forclaz and Philippe Martin (Rennes: Presses Universitaires de Rennes, 2015), 203-19; Lavenia, "Per apprestarsi alla battaglia: Catechismi cattolici e protestanti per i soldati (XVI-XVIII sec.); Una comparazione," Rivista storica italiana 129 (2017), forthcoming. 28 See Jeremy Black, European Warfare (1660-1815) (London: University College, 1994); John A. Lynn, Giant of the 'Grand Siècle': The French Army, 1610-1715 (Cambridge: Cambridge University Press, 1997); Michel Auvray, Lâge des casernes: Histoire et mythes du service militaire (Saint-Étienne: L'Aube, 1998); David Onnekink, ed., War and Religion after Westphalia, 1648-1713 (Farnham: Ashgate, 2009); Arnaud Guinier, L'honneur du soldat: Éthique martiale et discipline guerrière dans la France des Lumières (Seyssel: Champ Vallon, 2014). 
colonel, which was promoted by the Jesuit college of Lyon. ${ }^{29}$ Frequently reprinted, it was recast in $175^{8}$ by the Jesuit Carlo Melano di Portula (1715-61) for the soldiers of the king of Sardinia. The new edition had an unhappy history, incurring the hostility of certain Piedmontese ecclesiastics and the civil censors who were irked by its excessive fervor. ${ }^{30}$ In the same period, in 1759 , another Jesuit Pierre Daguet (1707-75) - already the author of a catechism for galley slaves-published, also in Lyon, the Exercices chrétiens des gens de guerre. Dedicated to Minister for War Charles Fouquet (1684-1761), who had pushed for the founding of the officers' college and other army reforms, it was shot through with patriotic rhetoric and depicted the chaplain as a "silent missionary," serving as a guide and comfort to the soldiery. ${ }^{31}$ Drawing its examples from the classical world and Claude Fleury's histories, Daguet's work was aimed principally at officers, encouraging them to respect the liturgical calendar, to attend Mass, to learn doctrine, to pray and to confess the sins common to soldiers. Among these he listed smuggling arms; the killing of children; gambling; arranging abortions; visiting brothels; reading superstitious, heretical or irreligious books ("these days," he observed with a touch of nostalgia, "wicked publications are no longer burnt"); ${ }^{32}$ using "immodest pictures or illustrations" (pornography). ${ }^{33} \mathrm{He}$ also inveighed against the honor culture: "a leftover of barbarism," the duel was evidence of a "crudity of custom" belonging to times unfamiliar with the politesse of the modern French officer. ${ }^{34}$ Daguet looked forward to a synthesis of civilization and catechism, of raison and foi, for discipline in speech, sexuality, and behavior. ${ }^{35} \mathrm{~A}$ good soldier should not be afraid to pray in the dormitories, even if devotion, in the age of Enlightenment, was looked on as the province of women and the effeminate. Faith did not undermine the service of the king; ${ }^{36}$ on the contrary, it bolstered discipline and curbed desertion — of which he spoke harshly—encouraging families not

29 Recueil d'édits [...], arrêts du Conseil, règlements et ordonnances du roi, concernant [...] l'École Royale Militaire (Paris: Le Mercier, 1752), 175-88; Heures militaires dédiées à la noblesse: Contenant des prières et instructions à l'usage des gens de guerre (Paris: de Hansy, 1745).

See Paola Bianchi, "Sotto diverse bandiere": Linternazionale militare nello Stato sabaudo d'antico regime (Milan: Franco Angeli, 2012), 142-43.

31 Pierre-Antoine-Alexandre Daguet, Exercices chrétiens des gens de guerre (Lyon: Delaroche, 1759), $x-x i$.

$32 \quad$ Ibid., 150.

33 Ibid., $155^{-63}$.

34 Ibid., 379-90.

35 Ibid., 229-31.

36 Ibid., 420 . 
to fear the profession of arms as a source of sin, and instead to have their children enroll:

Piety renders the warrior more feeling and more reasonable [...], in making him more honest and more integrated into society [...]. True courage [...] must always be conditioned by the laws of humanity [that] does not allow the victors to exploit all their advantage; it is a glorious thing to use victory with moderation: it is needful, as far as possible, to refrain from shedding enemy blood, [...] to spare women and children and all those not themselves bearing arms. ${ }^{37}$

Daguet talked up the droit de gens acknowledged by all "civilized" nations and steered clear of the vocabulary of holy war in a genre established to energize the fight against heretics and Muslims. Christians should care for the sick in the hospitals and conduct their wars with greater humanity than "idolaters" do. Soldiers, moreover, should avoid contact with women, even when handing over their laundry. ${ }^{38}$ Finally, when compulsorily billeted, they should not harass civilians or give rise to scandal; when on the march they should not despoil the countryside and when victorious, they should abstain from looting (the sin of theft) even when sanctioned by their commanders: the Turks generally avoided it. ${ }^{39}$ In conclusion, Daguet provided brief instructions for temporary military missions, drawing on the Jesuits' long experience in the field. ${ }^{40}$

Bourbon Spain, too, experienced in the eighteenth century a process of army reform that involved the drafting of new religious manuals for the soldiery-some being official productions, others not. ${ }^{41}$ Shortly before the Society's suppression, the Catalan Antonio Cordoniu (1688-1770), who would die soon afterwards in Italy, published a catechism which, instead of proposing norms for the conduct of soldiers in war, supplied religious instruction and military exempla culled from Jesuit history. This text, drafted around 1759, was aimed at officers and divided into six "procedures." According to the prologue, it had been commissioned by a colonel in order to "establish an enduring alliance between royal ordinances and the sovereign precepts of God's laws."42

\footnotetext{
37 Ibid., 429, 434.

38 Ibid., 49off.

39 Ibid., 510.

40 Ibid., 523-30.

41 See Manuel-Reyes García Hurtado, "Cuando el modelo de soldado se hallaba en los libros: Obras destinadas a alentar, instruir y advertir al militar español (mediados del siglo XVIII-principios del XIX)," in Milicia y sociedad ilustrada en España y América (1750-1800) (Madrid: Deimos, 2003), 1:621-42

Antonio Cordoniu, El buen soldado de Dios, y del Rey (Barcelona: Martí, 1766), "Prólogo."
} 
Cordoniu had himself occasionally filled the role of chaplain, but the experience had shown him that soldiers were generally ignorant of doctrine and they rarely confessed. A good pastor would meet them individually, encourage them to repent once a month, at least in peacetime, and work with them to elicit their essential Spanish, that is to say religious, natures. Men under arms additionally needed to remember that, as Christians, their neighbors might well be heretics, Moors, Jews or enemies. ${ }^{43}$ Over the centuries, the profession of arms had underwritten the nobility: if social distinctions were based only on the toga and not the uniform, blood hierarchies would have no basis. ${ }^{44}$ In ancient Rome, the elite came from the army, and after the advent of Christianity religion enabled soldiers to take care of both their bodies and their souls. Even in the modern world, the Commandments should be obeyed in precedence to military orders, avoiding pointless strife and respecting civilians, private property, chaplains, and sacred sites. As we read in 2 Maccabees 3:21-8, the Syrian commander Heliodorus was driven from the temple by armed angels. And as for women, Cordoniu told the story of a soldier who had received a fatal wound from a peasant defending herself against his molestations; before dying he had time to repent, but he would have better died in battle. Another generic story, with a penitential ending, concerned an experienced soldier who nurtured an infatuation for a beautiful woman and hoped to conquer her favors with money. He was deterred by her name, Mary, and the vow of chastity she had taken. Moved by these, the soldier helped her enter a convent offering a dowry; and when he died in battle, his soul was saved by the nun's prayers, for she had obtained from God for him sufficient time for the last rites. But even more than on the battlefield, it was in the hospitals that soldiers died "in their hundreds and thousands," riddled with syphilis, a just punishment for vice. They were incapable, it seemed, of being inspired by the chaste Judith who had beheaded Holofernes for a wanton glance. It was not war, then, but lust that had undone the Assyrians ("was it not the Hebrew woman that was the cause of that crash"). ${ }^{45}$ As well as policing their eyes, the soldiers should control their tongues because slanders and the violation of oaths ruined the reputations of their fellows and caused their deaths: by means of duels (which the Spaniards, with their obsession with honor, could not steer clear of), ${ }^{46}$ or through misinformation (which had led to the death of Wallenstein). "Let my tongue and my pen be like a fortress under siege. [They] will allow no gossip to enter nor slander to emerge."47

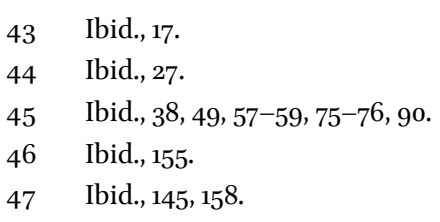


A soldier should fear only God, be content with his pay, which is just, ${ }^{48}$ and occupy his time avoiding idleness and evil company, reading good books, playing games honestly, walking in the fresh air, performing physical exercises and singing, as they do in Spain. These are only broad recommendations because it is the job of the king's ordinances and not the chaplain's to lay down guidelines for discipline "in matters regarding the suppleness of the body [...], warlike posture [...], keeping step, speed of movement, the handling of arms, orderly attack and retreat [...], and all the [...] maneuvers that go to make up a fine and formidable army." ${ }^{49}$ His duty, Cordoniu thought, was to provide model soldiers, such as the duke of Alba (1507-82), the ideal of the Catholic combatant. But there were also such examples in antiquity (Marcus Aurelius, who had heaven in his corner because he recruited many prayerful Christians) and in the Old Testament (like Joshua who punished Achan for his crimes, Joshua 7:1-26), the Gospels (the centurion) and early Christians such as Cornelius and Theodosius (379-95). Also of note are the crusading knights (if not always the purest of souls), Louis IX (1226-70) (not a great winner of battles, but a king who left his kingdom more prosperous), the heroes of Las Navas, Ferdinand of Aragon (r.1479-1516), Charles v (r.1519-1556) (more Spanish than Flemish), Eugene of Savoy (1663-1736) (who overcame the Ottomans at Belgrade thanks to a cloud that hid him from the enemy), and Raimondo Montecuccoli (1609-80). Not all soldiers triumphant in just and holy wars were above reproach, but the ways of the Lord are inscrutable and we should not rush to judgement. ${ }^{50}$ But there are brighter models still: the saints who were also soldiers (who are listed) and the Jesuits, such as the chaplain at Antwerp (Sailly?) who succeeded in converting with his rosary a hospitalized soldier. ${ }^{51}$ But Ignatius himself is the ideal type of soldier: the castle of Pamplona did not fall to the French until after he had been wounded in the leg:

He was a cadet and not a captain, but much admired and concerned never to pronounce a loose word; he kept his hands clean and would not besmirch them with pillaging [...]. He went on to found [...] my own Order, and mindful of his soldierly provenance, gave it the name of Company of Jesus. Not only that, but he called his Exercises [...] spiritual weaponry. My soldiers, you must imitate this great warrior if you wish to be recruited into the Army of Saints. ${ }^{52}$

\begin{tabular}{ll}
\hline 48 & Ibid., 43. \\
49 & Ibid., 93. \\
$5^{0}$ & Ibid., 82, 117-31, 141, 172. \\
$5^{1}$ & Ibid., 99. \\
$5^{2}$ & Ibid., 195-96, 164.
\end{tabular}


Ignatius was not the only model: Cordoniu relates how, during the expedition to conquer Acen, Francis Xavier $\left(1^{066-52)}\right.$ managed to gain the confidence of a dissolute soldier. The crew thought he was on board for the son of the viceroy, but Xavier was only concerned with this soldier, with whom he talked and played cards. One day he asked him how long it had been since he confessed and succeeded getting him to divulge his sins, which were grave and numerous as he had not received the sacrament for eighteen years and the vicar of Goa had even refused to absolve him. Xavier imposed him a small penance, but then, out of view, bared his own shoulders and proceeded to whip himself until he bled. The soldier was much struck by this, felt the weight of his sins and, kneeling at the feet of the saint who had flogged himself in his place, began to whip himself also, and converted. Another episode, heroic in a more strictly military sense, occurred when sixty ships and five thousand infidels appeared with hostile intent off Malacca. The governor was ill-prepared, but Xavier, as apostolic legate, equipped eight ships with 360 soldiers, promising them victory with divine assistance. He had them confess and take Communion and exhorted them to fight as an escuadron de Jesús, then brushing aside the governor's objections, led them into battle. Only four Christian soldiers and twenty sailors died, while the enemy fleet lost four thousand men, although the "Moors" were expert navigators. Returning to Malacca with rich booty and forty-five captured ships, he entered the city holding high a cross, to the applause of the people, like a David after beating Goliath, and ordered thanks to be offered up to "The God of Victories" for their miraculous triumph. ${ }^{53}$

The presentation of the Society as a militia was by no means new; ${ }^{54}$ the two episodes were borrowed and elaborated from Torsellini's biography, written before Xavier's canonization, and reprinted several times, including in Castilian. ${ }^{55}$ But Cordoniu was taking older models and adapting them to a time when military education had passed under the control of the civilian authorities. He also singled out a sinning ex-soldier (a "dishonest gambler, thief, and blasphemer") who became the blessed Carmelite friar Franco da Siena (1211-91), ${ }^{56}$ but he knew that in the Age of Enlightenment warrior priests no longer existed, in Europe at least. Their return would be provoked by the French Revolution and Napoleon, when the Spanish (and other) clergy mobilized to the extent of taking up arms and updating the concept of holy war against the

\footnotetext{
53 Ibid., 53-54, 103, 132-36.

54 See Gianclaudio Civale, "La Compagnia di Gesù, la guerra e l'immagine del soldato da Ignazio a Possevino (1546-1569)," Società e storia 36 (2013): 283-317.

55 Orazio Torsellini, Vida de San Francisco Xavier [...] traduzida [...] por el P. Pedro de Guzmán (Pamplona: Labàyen, 1620), 104ff, 121-23.

56 Cordoniu, El buen soldado, 204.
} 
Jacobin invaders. Some members of the order continued to serve as chaplains even after the dissolution of the Society, but it would not be the Jesuits who composed new and more militant manuals for Christian soldiers in response to the republican catechisms for soldats citoyens. ${ }^{57}$

\section{Restoration and the Search for a Catholic Patriotism}

After the restoration of the Society, one of the first soldiers' texts appeared in Italy, in the duchy of Modena, the site of a military academy. In this circumscribed ambience, which had hosted Ludovico Antonio Muratori (1672-1750), proponent of a Catholicism reconciled with Reason, Giovanni Regoli (17641844) sponsored the publication of the diary of a veteran who had drafted the manuscript for his son, just embarking on the profession of arms. This officer, wrote Regoli in his introduction, by no means subscribed to "the so-called philosophy of the century," which would have fathers and sons sever their emotional bonds as beasts do. His manual was a bit rough and ready ("we must not forget this is a soldier speaking”), but in an era when liberal secret societies and atheism threatened the Catholic faith, an unassuming style might be more conducive to the education of a zealous combatant than a catechism stuffed full of prayers. In any case, as we read in the diary, soldiers are like "strictly observant monks." "The soldier represents the civil authority and is an agent of law enforcement." Even so, some soldiers complained of being "chained mastiffs" fettered by uncongenial regulations. ${ }^{59}$ Even after the establishment of barracks the profession of arms seemed a millstone. But the art of combat was no longer the same: "a terrible scourge of humanity in every epoch, in recent centuries wars between Christian nations have been a little mitigated in their most disastrous repercussions." Was this due to a general civilizing process, or rather a benefaction of Christianity, which had gradually triumphed over barbarism and atavistic cruelty? One thing was certain: in Europe, the practice of

57 See Anton Dominik Auer, Militärisch-katechetisch-und praktische Predigten, 3 vols. (Graz: Miller, 1788). For the analysis of some anti-revolutionary texts for soldiers, see Vincenzo Lavenia, "Metodo, ragione, guerra: La letteratura catechetica per i soldati nel XVIII secolo," Società e storia 154 (2016): 767-85.

$5^{8}$ [Giovanni Regoli], Il soldato, ossia doveri morali [...] proposti da un distinto ufficiale di guerra a suo figlio [...] e pubblicati da un sacerdote della Compagnia di Gesù (Reggio: Davolio, 1819), 20. The work had at least three editions.

Ibid., 8-9. 
utterly destroying a defeated enemy had given way to the rules of international law that confined hostilities to those in uniform and tried to protect civilians:

An enemy soldier who lays down his arms ceases [...] to be an enemy and comes under the protection of the officer or soldier to whom he has surrendered. On entering a foreign country, the virtue of women, the innocence of children, the vulnerability of the old should be not only respected but protected [...]. Humanity insists on the rights the writer, the artist, and the merchant, going peacefully about their business. The peaceful farmer, who invites you to his fireside is your comrade and not your enemy. ${ }^{60}$

The Christian soldier should be the first to respect the droit des gens, but should be diffident about following the spirit of the times. For Regoli, who has recourse to Muratori's vocabulary, the atheist is a man who has substituted earthly happiness for the heavenly; but it is doubtful that he really disbelieves in God, as he claims, saying that religion is "metaphysical gibberish" aimed at the simple-minded. All peoples believe in the immortality of the soul. There may be the odd unbeliever endowed with a pinch of morality, but he exhibits his beliefs "out of some sort of conceit in distinguishing himself from the common run." "At the first cannon shot," he will invoke the name of God and "sometimes blaspheme openly as he dies." This is nothing to be surprised at: in times of peace libertinism can corrupt the strongest of spirits. With this in mind the old soldier tells his son of his own youth, when, as soon as he was out of the barracks, as a young officer he had frequented theaters and the salons of the ladies courted by his fellow officers, only to come away disillusioned. ${ }^{61} \mathrm{He}$ had even formed a friendship with a noble German Lutheran, who had led him towards lechery and introduced him to freemasonry, an offshoot of Protestantism and modern "Jewish deviancy":

These lodges are multiplying: you will be surrounded by proselytizers for freemasonry: steer clear of them as from a serpent's hiss. Deceitful sirens, they will entice you with a thousand blandishments [...]. Do not associate with them. Respect your religion which forbids it [...]. Do not be bashful of the religion of [...] Scanderbeg, of Monfort, of Theodosius [...]. Spurn the insulting babble of the philosophizing mob. ${ }^{62}$

$\begin{array}{ll}60 & \text { Ibid., 27-30. } \\ 61 & \text { Ibid., 30-38. } \\ 62 & \text { Ibid., 54-55. }\end{array}$ 
The time of holy wars was over, law and education were now widespread thanks to the barracks system, but the church now feared new dangers for the soldiery, and for Regoli freemasonry — a source of atheism — was the worst. Piety and military valor could go hand in hand, as many heroes past and present had shown, like Eugene of Savoy who died a good Christian asking pardon for his sins. Presented as a diary instead of as a catechism, his text avoided prayers and did not list the sins usually ascribed to soldiers. It belonged rather to a genre of booklets which were increasingly, in the course of the nineteenth century, accompanied by songs and musical pieces aimed at soldiers. ${ }^{63}$ But if in Regoli's manual religion was more to the fore than patriotism, in the Europe of nation states that followed on the fall of Napoleon, the tone of soldiers' catechisms had changed, as can be seen even in the texts written by members of the Society serving as chaplains.

In France, the Orléanist regime was not in favor of the establishment of a regular system of religious ministration to the armed forces, but this did not prevent chaplains from being active in a variety of circumstances. ${ }^{64}$ Thus before Napoleon III $\left(185^{2-70}\right)$ changed direction, the Jesuit Achille Guidée (1792-1866) drafted two distinct catechisms, one for sailors and one for soldiers. The second went through many editions and was translated into Italian (1853) and English (1856): the Catholics of the United Kingdom had in fact been recently emancipated, and the religious tutelage of those enrolling who declared their Roman adherence was a new issue. The two texts were published anonymously but carried the archbishop of Paris's official seal of approval. Opening with an admonition to soldiers to avoid vice (lust above all), the second manuel — which seems to be mainly aimed at chaplains-is essentially a bulky collection of prayers, passages from scripture and precepts, accompanied by spiritual exercises for confessing and Communion, and meditations that drew on the works of the Jesuit Dominique Bouhours (1628-1702). Nothing was said about the political situation, war or the fatherland, which other contemporary manuals occupied themselves with: it seems that Guidée, at a time of social upheaval, was advising the pastors of souls to stick to

63 See Chant religieux et militaire dédié aux soldats de l'armée française, set to music by the Belgian Jesuit Louis Lambillotte around 1820.

64 On the relationship between the clergy and the army in France, see Servir Dieu en temps de guerre: Guerre et clergés à l'époque contemporaine (XIX ${ }^{e}-X X I^{e}$ siècles), ed. Séverine Blenner-Michel and Jacqueline Lalouette (Reggio: Armand Colin-Ministère de la Défense, 2013). For the Jesuits alongside soldiers, especially in Metz and Lyon, see Joseph Burnichon, La Compagnie de Jésus en France: Histoire d'un siècle 1814-1914, 4 vols. (Paris: Beauchesne, 1914-22). 
religion. ${ }^{65}$ But in the second half of the century, while in France under the second Bonaparte activity in support of soldiers was promoted as one of the Society's missions, in Belgium patriotism engulfed the clergy of the newly constituted kingdom, which was about to embark on aggressive colonial exploits.

As we have seen, a literature aimed at the Christian soldier was honed in the Spanish Netherlands towards the end of the sixteenth century, when the Society's chaplaincies were established. But in the nineteenth century, the Belgian Jesuits took their inspiration not from their own past models, but from what was being written in France, and they played their part in constructing a pantheon of national heroes who might serve as examples for the new kingdom's combatants. Paul Barbieux, who would later abandon the Society, put pen to a controversial work in which he assumed guise of a chaplain to confute the errors of an imaginary Anglican minister, cousin to a Belgian colonel. ${ }^{66}$ In fact, the Jesuit was a chaplain in real life, in Ghent, and wrote a catechism that came out in abridged versions in Flemish and in French. The Manuel du soldat belge was officially approved by the country's leading bishops and the papal nuncio and opened with the name of the fatherland and of Leopold I (r.1831-65), who had acceded in 1831 swearing loyalty to the constitution. ${ }^{67}$ After the king, it was the flag that inspired Barbieux's most ardent flights:

The flag is the emblem, the symbol of all the battalions of the army, the badge $[\ldots]$ of their courage, their devotion and their honor [...]. Under that flag, the soldier expresses his loyalty to the King, to the Constitution, to the fatherland, to his superiors. Soldiers may die, felled by the bullets of the enemy, decimated by his machine-guns, bowled over by his cannons. But as long as the flag remains, however tattered [...]; as long as a fragment of the pole is still in the hands of an officer or a soldier who rise up again [...], soaked in their own courageous blood, the regiment too remains: it may die but it will not surrender, [and] the flag lives, rises again [...]. A soldier in the melee is conscious only of battle-cries, and the flag! In the name of God, in the name of the King, in the name of the fatherland, he follows his flag, looks up to it, fights for it. ${ }^{68}$

\footnotetext{
65 [Achille Guidée], Manuel du soldat chrétien (Paris: René, 1849).

66 Paul Barbieux, L'aumônier et le colonel, ou puissance de la vérité, 2 vols. (Tournai: Vandenbrouck, 1861).

67 Paul Barbieux, Manuel du soldat belge: Recueil patriotique et religieux (Tournai: Casterman, 1856), 15: "Soldiers, in the name of religion, the homeland, the army, for the life and death say: long live the King!"

Ibid., $16-17$.
} 
In an army, there are no rich and poor, peasants and bourgeois, industrialists and aristocrats, intellectuals and illiterates: the uniform makes everyone equal. In peacetime, the soldier is the guarantor of safety and prosperity, of private property and charity; in wartime, he demonstrates a courage disciplined by orders, by international laws, and by obedience: "a soldier's valor should never be vicious, or irresponsible or unjust, but always, human, wise, governed by the rules of justice, submissive to his superiors' orders, and always grounded in the essential doctrines of religion [...]. Never should the soldier transgress the droit des gens $[. .$.$] . This consists of a kernel of natural laws that all civilized peoples$ religiously observe." ${ }^{69}$ After all, war, like victory, soaks the earth according to a plan from God: “war is divine in its outcomes that are beyond men's reasoning. There are wars that prostrate nations for centuries, and others that raise them up. There are cursed wars and blessed ones."70 Belgium is Catholic and therefore her soldiers must be religious, more even than the Romans who punished impiety as treason; and more than the Muslims who condemn apostates to death. The Belgian soldier must love his family, the natural building-block of society; he must obey his leaders, who are fathers and mothers of their troops; they must show respect for their companions in arms and not accuse them before their superiors unless they have sure proof of some fault. The officers, for their part, must not be too intimate with their men, acknowledge that they need their soldiers and treat them with humanity, while suppressing dueling.

There is no human institution without a basis in religion, and this is no less true of an army. A clear conscience is not enough, whatever the philosophers say: without faith, the poor would rob the rich and the rich would not perform charitable works. It was not Christianity that ruined the Roman empire but the Epicureans, who denied the immortality of the soul, like modern atheists. A portion of the text is given over therefore to refuting contemporary religious errors, ${ }^{71}$ and another to recommending how true Christian soldiers should behave, visiting the sick, attending services, confessing after a thorough examination of their consciences, telling their rosaries, singing hymns and praying. ${ }^{72}$ The Christian soldier, furthermore, must maintain a proper demeanor and never neglect cleanliness and tidiness:

\footnotetext{
69 Ibid., 22-23.

70 Ibid., 28.

71 Ibid., 119-35.

72 Ibid., 187-224; the text contains a list of prayers and songs of the wars against Napoleon and the Netherlands. Then a guide for the spiritual exercises of a soldier and a brief catechism follow (225ff.).
} 
Disorderly hair, dirty mouth, teeth, ears, neck or hands, slovenly or incorrect uniform, shoes and feet in a poor state, worn buttons, unpolished belt, all these things are signs of the bad Christian, in so far as it is impossible to be a good Christian and a bad soldier [...]. In church, at the Communion rail, a smartly turned out soldier can often rouse tears of admiration. ${ }^{73}$

A soldier's diligence must extend to his free time, to combat such sins as lust, drunkenness, idleness, unbelief (the denial of the existence of hell can weaken the fear of death and punishment in the hereafter, without making soldiers bolder). For this reason, Barbieux extols the deployment of Catholic elites (magistrates, lawyers, doctors, bankers, writers, politicians) who dedicate themselves, in those cities where garrisons of soldiers are stationed, to charitable works, and organize innocent Christian evening entertainments for soldiers, particularly the poorer ones, before they are corrupted by drawing room habits. They should do this to provide some friendship to those who are often lonely, to instruct the less literate with the help of a small library of Christian books, to teach the rudiments of mathematics, writing and singing, to occupy their time with harmless games and to have them pray together at the end of meetings, particularly on Sundays, when a sermon in French and Flemish, the two languages of Belgium, should round off the day of rest:

We implore curates and Christian parents to encourage those who go off and enlist to profit from these good works which offer them a safe means of adhering to the straight and narrow. This advice is particularly aimed at those soldiers who would prefer a pleasant, [...] decent, patriotic [...] and Christian evening to cabarets and bordellos where they will only lose their affection for military discipline and traduce the duties they owe to their fine country. ${ }^{74}$

As we will see, the idea of Christian military evenings was an import from France. Barbieux omits saying so, and sets up examples of compatriots who have proved themselves over the centuries worthy models of sanctity and heroism: a pantheon starring in particular Godfrey of Bouillon (1060?-1100), who had been the leader of the First Crusade against the Mohammedans. Belgium was his homeland, as he proudly underlines; therefore, the overall failure of the crusades notwithstanding, that great knight, who had overcome the

\footnotetext{
73 Ibid., 56 .

74 Ibid., 59-61.
} 
"Islamic hordes," deserves greater admiration than Alexander the Great and Caesar. ${ }^{75}$ Alongside Godfrey, Barbieux puts up the Ghent-born Charles v, praised for his military skill, political flexibility and readiness to abdicate. No sovereign ever showed a greater love for Belgium or more determination to keep those provinces united. ${ }^{76}$ Passing over in silence the years of the wars of religion which had split the Flemish territories, the Jesuit praises instead those who had fought with the Habsburgs against the Turks, and above all the Dragons Walloons who had proved their worth from the War of the Polish Succession onwards and had later opposed the advance of the revolution before declaring fealty to Leopold I. ${ }^{77}$ Another exemplary soldier was François de Croix, count of Clerfayt (1733-98), hero of the anti-French wars, whose choice of a life in uniform (remaining single) had been hard-earned. As in the case of the young Jesuits who decided to don the habit of the Society in defiance of their parents' wishes, ${ }^{78}$ "his mother, a widow, had opposed the vocation that seemed to be taking him towards a career under arms, so he had to learn German, essential for his project, in secret, and wait until he was twenty [...]: only then was he able to extract from her, as it were, permission to wear the uniform." ${ }^{79}$ In addition to the champions of the war against revolutionary France and Napoleon, there were soldiers, especially the partisans de Capiaumont, who had distinguished themselves in the struggle for independence against Netherlands. One of these showed a truly peerless dedication to his homeland:

One of this squadron, Pluymers by name, $[. .$.$] had his arm shattered by an$ enemy bullet; when the damaged limb had to be amputated, the chief of the partisans, to console the poor soldier, promised him a good pension; but [he] strenuously refused and asked to be allowed to remain with his companions and be permitted to learn the trumpet to sound the charge against the enemies of his Country, since he could no longer fight with his carbine. His request was granted. 80

As we can see, a leaning towards patriotism and the aesthetic of sacrifice for the Nation had infused religious manuals for soldiers. So much is again




demonstrated by a second text that appeared in those years, although in large part written in 1825, La bravoure militaire alliée avec le sentiment religieux by the Belgian Jesuit Jean Baptiste Boone (1794-1871), a chaplain and promoter of the cult of the Sacred Heart, ${ }^{81}$ previously an open opponent of the Napoleonic clergy. The book was published by Father Édouard Terwecoren (1815-72) in the series of Précis historiques (a goldmine for the history of religious support for the soldiery), and copied whole sections from other works of overheated national sentiment like Charles-Ignace Le Mayeur's La gloire belgique (1816). There was no truth in the idea insinuated by the philosophes, following Machiavelli's lead, that faith was incompatible with a martial spirit; rather it comforts souls and promotes courage by overcoming the fear of death. As even the Lutheran Gustavus Adolphus of Sweden (r.1611-32) had said, the best Christian was also the best soldier. As for others who had written catechisms for soldiers before him, the Old Testament is a source of examples that disprove any incompatibility between faith and valor. And these were not only masculine models, but women too, like Deborah and Judith: "passion, determination, a love for order and an active charity are always the offspring of religion. A largeness of spirit, love for one's country, for true glory, the sacred scriptures are presented as the most excellent of virtues. All the generous sentiments that we admire in God's people reach their perfection in the Catholic religion." ${ }^{82}$ Even Edward Gibbon (1737-94) acknowledged that Constantine was a great warrior, and in the Middle Ages, the military orders (such as the Teutonic Knights, unfortunately suppressed) had demonstrated the extent to which faith and soldiering could go hand in hand. With Bouillon, the cross had triumphed over barbaric Asia, and in modern times soldiers renowned for piety were numerous: the knights of the Order of the Golden Fleece, Charles v, Don Juan of Austria (1547-78), the Prince of Condé (1621-86) even, for all that he was not without his vices. Boone, in short, did not only foreground models already well-known to Christian soldiers' literature, but he exalted as an intrinsic value the warlike ethos of past military heroes, not eschewing fabricated stories in order to give their campaigns a sacred gloss. But recent battles too had had their ideological content, and Boone was only too happy to declare his adherence to Catholic mobilization against the modern world, a mobilization that had dusted off the idea of holy war against the enemies of religion and the social order. At the time of the revolution, the old spirit of the Christian soldier had been reignited

\footnotetext{
81 On militant meanings of this devotion, see Daniele Menozzi, Sacro Cuore: Un culto tra devozione interiore e restaurazione cristiana della società (Rome: Viella, 2001).

82 Jean B. Boone, La bravoure militaire alliée avec le sentiment religieux (Bruxelles: Vandereyt, 1853), 8 .
} 
particularly in the Vendée, where the rebels had resisted the assaults of the unbelievers (as the Jesuit Crétineau-Joly saw it). ${ }^{83}$ That community had shone like a star on a dark night, re-establishing the knighthood of old and showing an attachment to God, the church, and the legitimate sovereign that the Jesuit found moving. The people of the Vendée had preferred

rather to die than to give up their religion, their God and their king. Three times a day these heroic peasants met together to recite the rosary. Laugh if you will, you godless of the earth! These fearsome bands [...] overcame a hundred times the soldiers of the goddess Reason, ten times their number [...]. It was wonderful to see those soldiers so awesome in combat beating their chests before the ministers of mercy and confessing their penitence for some venial plundering or a harshness committed in the heat of battle [...]. It was wonderful to see [...] these glorious troops, condemned by the revolutionary tribunals march towards death singing "Salve Regina." ${ }^{4}$

But the ultimate victory of religion over the goddess Reason, whose cult was celebrated in Paris, was complete only when the exiled Napoleon was forced to recognize the greatness of Christ and the true faith, dying comforted by two priests. ${ }^{85}$ Boone in fact does not hesitate to appropriate the myth of the soldier Bonaparte's Christian death and to paraphrase whole passages from the apologetic works of Robert-Augustin de Beauterne (1803-46), Mort d'un enfant impie (1837) and Sentiment de Napoléon sur le christianisme: Conversations religieuses recueillies à Sainte-Hélène (1843). And what could be a more perfect celebration of the power of God than the defeat in war of the enemies of the church?

This is our God, venerated for eighteen centuries in Europe, for whom millions of Christians have given their lives [...]. This is the God of the great and the humble, of emperors and their subjects, of the educated and the ignorant! This is the God of Charlemagne of Saint Louis Ix [...], of Napoleon! This is the God [...] whose priests Voltaire, the archbishop of unbelief [...], called on loudly from his dying mouth: with that same mouth that for sixty years had vomited forth insults and nonsense and profanities!86

\footnotetext{
83 Although not mentioned, the author knew the Histoire de la Vendée militaire by Jacques Crétineau-Joly (1840-42).

84 Boone, La bravoure, 27-28.

85 Ibid., $37-51$.

86 Ibid., $5^{2}$.
} 
Boone copied also entire pages from the ultra-Catholic writings of the French marquis Anatole de Ségur (1823-1902), ambassador to Rome, author of various collections of popular tales and volumes aimed at moralizing and Christianizing the soldiery. ${ }^{87} \mathrm{He}$ had also been a promoter, alongside the Congregation of the Mission (which had since the seventeenth century shared with the Jesuits the job of providing chaplains to the armies of France) of those soirées militaires that later spread to Belgium. Boone appropriates a long passage in which Ségur, matching religion to army service, had compared priests with soldiers, both of them uniformed, both bound by norms of communal life, both subject to a hierarchy, both without families, both dedicated to sacrifice for God and the polity, both committed to expanding Christianity through colonial conquests and foreign missions. ${ }^{88}$ The barracks, for Boone as for Ségur, was a sort of cloister or friary, even if its disciplinary regime was more basic. ${ }^{89}$ To encourage the missionary work of the soirées, Boone goes on to cite a text of the Abbot Isidore Mullois (1811-70) (the Manuel de charité, 1851) and praises the example of another Frenchman, the herbalist Germain-ville of Bordeaux, who in the name of piety, with the help of a few priests, dedicated his life to the education of soldiers (he also arranged a reprinting of Guidée's manual to be circulated among the Lazarites):

While still in the prime of life, he abandoned a flourishing trade to dedicate himself entirely to the moral well-being of soldiers; he devoted to them all of his time, his energy, his means, his heart, all of his life. He [...], wherever called upon, is always ready to bring the succour of his dedication and his experience; he knows soldiers well, he loves them, and he discovers hearts among them equally ardent in love, gratitude too being among their virtues. ${ }^{90}$

With the rise of militarism throughout Europe, religious publications aimed at soldiers multiplied in Belgium, and the Jesuits played their part both in French and in Flemish. ${ }^{91}$ Moreover, missionaries were soon to accompany the forces of Leopold II (r.1865-1909) in his brutal conquest of the Congo. But it was

$87 \quad$ See Les derniers jours d'un soldat condamné à mort and Les mémoires d'un troupier, which appeared in more than ten printed editions.

88 Boone, La bravoure, 53-62. See Anatole de Ségur, Le dimanches de soldats: Contes et récits (Paris: Lecoffre, 1852), 197-208.

89 See Anatole de Ségur, La caserne et le presbytère: Contes et récits (1857), which had several editions and was translated into Italian.

$90 \quad$ Boone, La bravoure, 65 [footnote].

91 The Handboek van den Christen Soldaat: Godsdienst en Vaderland (Bruxelles: In het Secretariaat des Genootschaps van den H. Vincentius a Paulo, 1870) is attributed to the Jesuit 
France during its conflict with Lutheran Prussia that saw the widest dissemination of catechisms of all sizes: some of these were old ones rechauffés for the occasion, others new, such as a sprightly text by the Jesuit Marin de Boylesve (1813-92), an ardent promoter of devotion to the Sacred Heart. ${ }^{92}$ In Italy, after the Unification (1870), notwithstanding the animosity between the new state and the church of Rome, and the successive liberal governments' mistrust of military pastoral initiatives up until the First World War, a catechetical literature directed at the troops still flourished, inaugurated by an anonymous work attributed to Giovanni Battista Cossali, a Jesuit rector at Venice. ${ }^{93}$ Towards the end of the century this was joined by a translation from the French of a text drafted by a science teacher from the Gregorian University well-known for his writings on the Galileo episode, Bellino Carrara. ${ }^{94}$ Nonetheless, for many years Italy lacked a patriotic clergy on the Belgian model, while in France the situation was more complex. ${ }^{95}$ At the end of the nineteenth century, after the presence of chaplains in the armies of the Third Republic had been regularized (not excluding those in the colonies), debate on the ethics of war was exploited as a tool against leftist radicalism, to the extent that Charles Daniel expounded for enrolled soldiers the story of Alexis Clerc (1819-71), a fighting priest, hailed as a martyr of the Commune and a model of the ideal soldier-chaplain. ${ }^{96}$

Charles Verbeke. Perhaps the book is the work of the Vincentians and resumed the textual format adopted by Guidée in France.

Marin de Boylesve, Dieu et patrie: Ordre du jour proposé au soldat chrétien (Paris: Haton, 1870).

93 Il soldato di Cristo confortato alla lotta (Venice: Tipografia Emiliana, 1872). For Italy, see Maria Paiano, "Religione e patria negli opuscoli cattolici per l'esercito italiano: Il cristianesimo come scuola di sacrificio per i soldati," Rivista di storia del cristianesimo 8 (2011): 7-26.

94 Bellino Carrara, Il libro del soldato cristiano: Versione dal francese con modificazioni e aggiunte (Milan: Palma, 1894).

95 For an overall picture to over the Dreyfus affair, see Xavier Boniface, L'Armée, l'Église et la République (1879-1914) (Paris: Nouveau Monde/DMPA, 2012).

96 The work was published with two titles: Charles Daniel, Alexis Clerc: Marin jésuite et otage de la Commune fusillé [...] le 24 mai 1871 (Paris: Téqui, 1895); Daniel, Soldat de France et soldat de l'Eglise: Alexis Clerc, [...], jésuite, martyr de la Commune (Lille: Maison Saint-Joseph, 1897). Former sailor and chaplain and missionary in the East, Clerc had been sentenced to death by the revolutionaries along with four other fathers already celebrated by Armand Pontlevoy (Actes de la captivité et de la mort des Rr. Pp. P. Olivaint, L. Ducoudray, J. Caubert, A. Clerc, A. de Bengy, de la Compagnie de Jésus). See John W. Padberg, Colleges in Controversy: The Jesuit Schools in France from Revival to Suppression, 1815-1880 (Cambridge, MA: Harvard University Press, 1969), 253-54. 
To conclude, a journey through the manuals for soldiers written by Jesuits demonstrates how far these writings, pioneered by the Society, went in absorbing a patriotic rhetoric quite extraneous to the earliest catechisms. Up until the mid-seventeenth century these texts, written by chaplains active for Spain before the establishment of barracks, aimed at providing a model of both religious discipline and pastoral care with a view to moulding a new type of army, orderly and motivated to fight in defense of the Catholic faith. Later, when the wars of religion came to an end, a number of French-language manuals began to exhibit a growing inclination towards the language of nationalism. In eighteenth-century Europe, army reforms, if on one hand they succeeded in imposing a discipline hitherto only dreamed of, on the other relegated the presence of chaplains, now absorbed into the military hierarchy, to an ancillary role. And this is reflected in the catechisms, which took on board the values of international law, adopting a vocabulary more in harmony with the times, and limited themselves to supplying religious instruction. In this context, before the suppression, as the Jesuits were denouncing secularization, they were putting forward saintly models from the order's past as ideals of soldiering. After the revolution, the Society again committed itself to the education of soldiers in far from favorable circumstances, exalting the concept of the Christian soldier against "modern atheism," and promoting forms of healthy socialization for the soldiery. In Belgium, the coming to power of a liberal regime dominated by Catholics was helpful to a missionary effort by chaplains strongly colored by patriotism. Later still, the mystique of the nation would affect a large proportion of the texts destined for soldiers and chaplains sent to the front in the First World War. 